\title{
COMMENTS
}

\section{SEVERABILITY OF EMPLOYEE COVENANTS NOT TO COMPETE}

I

Employers frequently seek protection from the competition of former employees through the use of restrictive covenants in employment contracts. ${ }^{1}$ In most states covenants not to compete are recognized as valid ${ }^{2}$ as long as the restrictions do not exceed what is reasonably necessary for the protection of the employer and are not unduly oppressive upon the employee. This rule, however, does not admit of easy application and the subject abounds with litigation. ${ }^{3}$

Where covenants not to compete have been adjudged unreasonably broad when viewed as a whole, most courts have endeavored to grant partial enforcement by the use of the doctrine of severability. As first applied in England to restrictive covenants, ${ }^{4}$ the doctrine provided that if in terms appearing on the face of the instrument the excessive restraint were severable from what was found to be a reasonable restraint, the excessive restraint could be disregarded and the remaining part of the covenant enforced. ${ }^{5}$ Conversely, if the excessive

${ }^{1}$ Protection from competition by the use of restrictive covenants is more frequently sought by purchasers of proprietary interests.

${ }^{2} \mathrm{~A}$ few jurisdictions have statutes which render void employees' covenants not to compete. Consult note 26 infra. Similar agreements by sellers of business concerns are not prohibited in any jurisdiction.

${ }^{3}$ For collections of recent cases consult Arthur Murray Dance Studios of Cleveland v. Witter, 105 N.E. 2d 685 (Ohio C.P., 1952); Enforceability of Restrictive Covenant, Ancillary to Employment Contract, as Affected by Duration of Restriction, 41 A.L.R. 2d 15 (1955), Enforceability of Restrictive Covenant, Ancillary to Employment Contract, as Affected by Territorial Extent of Restriction, 43 A.L.R. 2d 94 (1955). For recent cases on restrictive covenants connected to the sale of a business, consult Enforceability of Covenant against Competition, Ancillary to Sale or Other Transfer of Business, Practice, or Property, as Affected by Duration of Restriction, 45 A.L.R. 2d 77 (1956); Enforceability of Covenant against Competition, Ancillary to Sale or Other Transfer of Business, Practice, or Property, as Affected by Territorial Extent of Restriction, 46 A.L.R. 2d 119 (1956).

${ }^{4}$ An early case was Chesman v. Nainby, 2 Ld. Raym. 1456, 92 Eng. Rep. 447 (1725). The defendant had promised not to engage in linen draping within one-half mile of plaintiff's then dwelling house or any dwelling house to which plaintiff might repair. The court found the defendant in breach for competing within one-half mile of plaintiff's then dwelling house but suggested that the added restraint was invalid. The situation was analogized to where a bond was given "with condition to do several things, and some are agreeable to the law, and some against the common law [wherefore] the bond shall be good as to the doing the things agreeable to law, and only void as to those that are against the law." Tbid., at 1459, 449.

${ }^{5}$ In Rogers v. Maddocks, [1892] $3 \mathrm{Ch} .346,348$, the defendant had agreed that for two years he would not engage in the sale of "beer, ale, porter, or other malt liquors, aerated waters, 
restraint were incapable of grammatical severance from the reasonable restraint, the entire covenant was unenforceable. Often termed the "blue-pencil" test, it was said that severance could be achieved only when a blue pencil could be run through the excessive restriction. ${ }^{6}$

The severability doctrine is often said to represent the majority view in the United States, ${ }^{7}$ but its application has been so varied that the current form admits of no general statement and the original doctrine is often barely recognizable. In addition, the entire concept of severability has increasingly come under direct attack with diverse results, as demonstrated by two recent cases. In Fullerton Lumber Co. v. Torborg, ${ }^{8}$ the Wisconsin Supreme Court abandoned the severability doctrine by ruling that whether the covenants were severable or not a restriction that was invalid as a whole could be enforced in part insofar as it was reasonable and not oppressive. ${ }^{9}$ Shortly thereafter a federal court of appeals, applying North Carolina law in Welcome Wagon v. Morris, ${ }^{10}$ held that a restriction invalid as a whole could not be partially enforced irrespective of severability. Though the covenant in question was clearly severable in terms, the court said, per Dobie J., that "the restrictive covenant must be judged as a whole and must stand or fall when so judged."11

wines, spirits, cordials, tobacco, or cigars ... within 100 miles of the general postoffice in Cardiff...."The court upheld the restriction as to the sale of malt liquors, the other restrictions though invalid were severable.

"For a current statement of the "blue-pencil" test see John Roane, Inc. v. Tweed, 33 Del. Ch. 4, 89 A. 2d 548 (1952).

7 E.g., "[w] $w$ here a promise in reasonable restraint of trade in a bargain has added to it a promise in unreasonable restraint, the former promise is enforceable unless the entire agreement is part of a plan to obtain a monopoly; but if full performance of a promise indivisible in terms, would involve unreasonable restraint, the promise is illegal and is not enforceable even for so much of the performance as would be a reasonable restraint." Rest., Contracts $\S 518$ (1932).

8 -Wis.-, 70 N.W. 2 d 585 (1955).

${ }^{9}$ Torborg had agreed to refrain for ten years from engaging in a business similar to plaintiff's lumber business "in any city, village, or town, or within a radius of fifteen miles thereof, where $I$ have served as manager for the company within a period of five years preceding the date of termination of my employment." Ibid., at - 586. Upon quitting plaintiff's employ Torborg opened a competing lumber yard in Clintonville, Wisconsin, whereupon plaintiff brought an action seeking to restrain Torborg from competing within fifteen miles of Clin. tonville for ten years. The court found that plaintifi had suffered irreparable damage, but also ruled that the time restriction was unreasonably long, and suggested that three years would constitute a minimum time during which the defendant could be enjoined. In remanding the cause for a determination on a reasonable time, the court acknowledged "that the rule of partial enforcement of indivisible promises is a departure from that which this court has adhered to in the past." Ibid., at -,592. One justice dissented on the ground that the time restriction was not divisible in terms and so could not be partially enforced.

${ }^{10} 224$ F. 2 d 693 (C.A. 4th, 1955).

11 Tbid., at 701. Defendant was hired as a "hostess" at Welcome Wagon's widespread advertising and public relations agency in Gastonia, N.C., and agreed to refrain for five years from engaging in a similar business "(1) in Gastonia, N.C., and/or (2) in any other city, town ... or other place in the United States or Canada in which [plaintiff] . . . is then engaged in rendering his said services, and/or (3) in any city, town... or other place in the United 
This comment will first attempt to review briefly the various interpretations and resultant erosion of the doctrine of severability as applied to restrictive covenants in employment contracts. The doctrine of severability of covenants restraining competition will then be evaluated in terms of the fundamental issues involved in the enforcement of restrictive covenants. ${ }^{12}$

In the case most commonly cited to illustrate the traditional statement of the severability doctrine, ${ }^{13}$ the defendant had agreed to refrain from carrying on the perfumer's trade "within the cities of London or Westminster, or within the distance of 600 miles from the same." Subsequently, defendant engaged in the perfumer trade in London, and the court upheld plaintiff's claim for liquidated damages for breach even though the restraint was too broad in its entirety, since the restraint was valid as to London and Westminster, and the remaining excessive restriction could easily be stricken from the face of the contract.

There are few states which adhere strictly to the traditional "blue-pencil" test, ${ }^{14}$ although in many jurisdictions such adherence is professed. Two New

States or Canada in which [plaintifi] . . . has been or has signified his intention to be engaged in rendering his said services." Ibid., at 696 . The court reversed a lower court's finding that defendant's new business was not the same as plaintifi's business but held for the defendant on the ground that the contract was invalid because the territorial and time restrictions were unreasonably broad. This aspect had not been considered by the district court. In response to the contention that the covenant was severable and might be enforced as to Gastonia, the court said the restriction must be judged as a whole.

Although the court stated that none of the cases cited to it militated against the view that partial enforcement could not be granted, one of them plainly did grant partial enforcement of a restrictive covenant. Hauser v. Harding, 126 N.C. 175,35 S.E. 586 (1900). Also, the court directed attention to John T. Stanley Co. v. Lagomarsino, 53 F. 2d 112 (S.D. N.Y., 1931), where a clearly severable covenant was partially enforced. These peculiarities in the Welcome Wagon opinion, as well as others, are noted in Severability of Covenants in Partial Restraint of Trade: A New Rule, 5 Duke B.J. 115 (1956).

12 Severability will be examined almost wholly in reference to employment contracts, and restrictive covenants ancillary to the sale of a business will be discussed only incidentally. For the treatment that has been accorded the latter area consult 45 A.L.R. 2d, op. cit. supra note 3 and 46 A.I.R. 2d, op. cit. supra note 3 , and for the precedent value of the business sale on the employment covenant consult note 24 infra. Further, this comment will not be concerned with that vast body of law dealing with what is necessary to satisfy the requirement of reasonableness for restraints of trade. Consult authorities cited in note 3 supra setting forth criteria for the determination of reasonableness.

13 Price v. Green, 16 M. \& W. 346, 153 Eng. Rep. 1222 (Ex., 1847).

"Illinois follows the original rule. In Interstate Finance Corp. v Wood, 69 F. Supp. 278, 279 (E.D. Ill., 19:6), the defendant had agreed not to loan money nor write insurance for one year after termination of his employment contract "in any State in which ... [plaintifi] now is or shall hereafter be so engaged." Plaintift sought to restrain defendant from engaging in such business in the seven Illinois counties in which plaintiff maintained offices. The court denied enforcement. "If the contract had contained separate restrictive clauses applying to separate geographical areas ... [and] if ... plaintiff's reasonable interests being subjected to injury extended over any one or more of the limited areas, the covenants applicable to them, being lawful, could be enforced and the illegal covenants disregarded. [Citations omitted.] But where the contract contains but a single territorial covenant and it is void as being in unreasonable restraint of trade ... the entire contract must fall." Ibid. Accord: Stanmeyer $v$. Davis, 321 Ill. App. 227, 53 N.E. 2d 22 (1941). Cf. Pelc v. Kulentis, 257 Ill. App. 213 (1930). 
Jersey cases are among the earliest American decisions liberalizing the rule. In one, a covenant prohibiting the sellers of a pottery-making business from manufacturing pottery for fifty years "within any state in the United States ... except in ... Nevada and ... Arizona," was held to be severable because it embraced several areas disjunctively described, and was, therefore, enforceable as to the state of New Jersey..$^{15}$ Increasingly thereafter severance was effected by judicial interpolation of divisibility into the terms of a contract thus abandoning the requirement of literal grammatical severance. ${ }^{16}$ Doctrinal nuances developed and many courts, buttressed by the maxim that parties are presumed to have intended a valid contract, ${ }^{17}$ held that if the instrument indicated any lines of division at all the contract would be construed as severable. ${ }^{18}$ All territory is capable of physical division, and accordingly the divisibility required to grant partial enforcement could easily be found. ${ }^{19}$ In most jurisdictions, how-

${ }^{15}$ Trenton Potteries Co. v. Oliphant, 58 N.J. Eq. 507, 43 Atl. 723 (1899). Rules of construction were said to allow divisibility since the contract read is rather than of the United States. The court cited E. Underwood \& Son, Ltd. v. Barker [1899] $1 \mathrm{Ch}$. 300, 301, where the covenant read "in the United Kingdom of Great Britain and Ireland, or in France, or in the Kingdom of Belgium, or Holland, or in the Dominion of Canada," and was obviously grammatically divisible.

A similar application of what was later termed "selective construction" appeared in Fleckenstein Bros. Co. v. Fleckenstein, 76 N.J.L. 613, 71 Atl. 265 (1908), where the defendant had agreed not to compete "within five hundred miles from . . . Jersey City, N.J. . . . within the period of twenty years." The contract was held divisible and enforceable as to Jersey City, since it could be read as "either in the city of Jersey City or within five hundred miles from that city." Thus there was said to be two areas disjunctively described.

${ }^{16}$ For comment considering the development consult Severability of Covenants in Partial Restraint of Trade: A New Rule, 5 Duke B.J. 115 (1956); Employee's Agreement Not to Compete, 26 N.C.I. Rev. 402 (1948); Divisibility of Contract in Restraint of Trade, 5 U. of Newark L. Rev. 124 (1940); Injunctions Against Breach of Negative Covenant in Personal Service Contract, 22 Cornell L.Q. 246 (1937); Partial Enforcement of Unreasonable Restraints, 22 Va. L. Rev. 94 (1935); Unreasonable Agreements in Restraint of Trade, 15 B.U.L. Rev. 831 (1935); Application of the Rule of Severability to a Covenant in Restraint of Trade, 82 U. of Pa. L. Rev. 872 (1934).

${ }^{17}$ For example, this "presumption" was very helpful in Fleckenstein Bros. Co. v. Fleckenstein, 76 N.J.L. 613, 71 Atl. 265 (1908).

${ }^{18}$ E.g., Burroughs Adding Machine Co. v. Chollar, 79 S.W. 2d 344 (Tex. Civ. App., 1935); Hommel Co. v. Fink, 115 W. Va. 686, 177 S.E. 619 (1934); cf. Wyder v. Milhomme, 96 N.J.L. 500,115 Atl. 380 (1921).

19 Where the rule of severability has been invoked in respect to territorial restrictions, or to a line of goods, courts have rather freely reduced the time restriction when found to be unreasonable. Analytically, the time restriction itself is not susceptible of literal grammatical division; perhaps the "blue-pencil" test was never meant to apply to it. An early example of a reduction in the time restriction can be found in Oregon Steam Navigation Co. v. Winsor, 20 Wall. (U.S.) 61 (1873). The Oregon company purchased a steamer from a California company subject to a prohibition on use in California waters for ten years. Three years later the Oregon company sold the steamer to defendants subject to the stipulation that it could not be run either in California waters or on the Columbia River for ten years from date of sale. Plaintiff, Oregon company, sued for breach of the covenant, and the court found the restraint too broad because the restriction as to the California waters extended three years be- 
ever, the construction has not been liberalized to the breaking point-where the contract affords absolutely no basis whatsoever for divisibility, partial enforcement will not be granted..$^{20}$

A few states, however, (notably Massachusetts) have gone to the extreme of ruling that all contracts may be construed to be severable irrespective of the language employed in the contract, ${ }^{21}$ Classifying this under the doctrine of severability is manifestly anomalous, since severability has meaning only in reference to contractual language, whether literal or not. In fact, the Massachusetts practice has been cited to represent a trend to grant partial enforcement irrespective of divisibility.22 The considerable development of this "trend"

yond the period for which plaintiff was bound to the California company. But plaintiff was permitted recovery because the California portion of the covenant was divisible, and so could stand for the seven years for which the plaintiff was bound and be void as to the rest. But query whether the time restriction itself was divisible.

${ }^{20}$ The Ner- Jersey- courts, for example, have limited the strained construction given in the Trenton Potteries and Fleckenstein cases, note 15 supra. In Wyder v. Mfilhomme, 96 N.J.L. $500,502-03,115$ Atl. 380, 381 (1921), the New Jersey court denied partial enforcement of a sellers' covenant not to compete in the United States, distinguishing the above cases where "the court adopted a rule of selective construction of the contract whereby it was enabled to confine the operation of the contract to a territory deemed reasonable.... The present covenant admits of no such construction, for where it mentions any territory at all it speaks of 'the United States of America' without any hint of a subdivision thereof." In Automobile Club of Southern New Jersey v. Zubrin, 127 N.J. Eq. 202, 12 A. 2d 369 (Ct. of Ch., 1940), partial enforcement was denicd where an employment covenant prohibited competition "anywhere in Southern New Jersey south of Trenton, New Jersey." The court noted that where divisibility was found in the early cases the contracts were susceptible to division without violence to the express language of the contracts. But here the court held the contract was not capable of a divisible or selective construction. However, it would seem that the grammatical form of the contract in Zubrin was very similar to that in Trenton Potteries; it is probably significant that the latter dealt with a restrictive covenant ancillary to the sale of a business rather than to employment.

Also, compare Hommel Co. v. Fink, 115 W. Va. 686, 177 S.E. 619 (1934) with Pancake Realtv Co. v. Harber, 137 IT. Va. 605, 73 S.E. $2 d 438$ (1952).

${ }^{21}$ In the leading Massachusetts case, Edgecomb v. Edmonston, 257 MIass. 12, 16, 20-21, 153 N.F. $99,100,102$ (1926), the defendant-employee had agreed not to compete with his employer "within the Commonwealth of Massachusetts for a period of five years," and the agreement was held binding as to Boston only. The court said that "the theory of the divisibility of space as applied to this contract is consonant with public policy and is more consistent with the intent of the contract than is the contention that the negative covenant is not enforceable in equity, in whole or in part, because the unit of space is not so described as to indicate its component territorial parts and divisions." See also Brannen v. Bouley, 2i2 MIass. 6 172 N.E. 104 (1930); Whiting Jilk Cos. v. O'Connell, 27 T MLass. 570, 179 N.E. 169 (1931); Metropolitan Ice Co. v. Ducas, 291 MLass. 403, 196 N.E. 856 (1935).

2 Foltz r. Struxness, 168 Kan. 71t, 215 P. 2d 133 (1950); 5 Williston, Contracts $\$ 1660$ (rev. ed., 193i). The trend may be desirable, but its basis in law is suspect. Edgecomb v. Edmonston, 25i Mass. 12, 153 ‥E. 99 (1926), which started the trend, rested on dubious authorities, some directly contrary to the rule for which they were cited. Subsequently the rule became imbedded in Massachusetts by a circular interdependence on Massachusetts and other cases that relied on the Edgecomb rule. For an unfolding of the Massachusetts trend and exposition of the authorities relied on in the Edgecomb case, consult Uinreasonable Agreements in Restraint of Trade, 15 B.U.L. Rev. $83 \pm$ (1935). 
is evidenced by cases dealing with covenants not to compete in contracts for the sale of business enterprises. ${ }^{23}$ However, in cases dealing with restrictive covenants in employment the development is much less clear, and it is doubtful that cases dealing with covenants restraining business competition are valid precedents for employee restraints. ${ }^{24}$

There are, then, three separate but overlapping approaches within the severability doctrine: First, that severability can be achieved only by grammatical severance of the literal terms of the contract. Second, that a contract will be construed as divisible whenever the court can find an indication in the instrument of any line of division-probably the preponderant United States view. Third, that contracts may be construed as divisible irrespective of whether the contract itself affords any basis for such division. ${ }^{25}$

Finally, all these approaches are rejected by the Torborg and Welcome Wagon views as well as by the few statutes that make all agreements by employees not to compete illegal..$^{26}$

${ }^{23}$ E.g., Eldridge v. Johnston, 195 Ore. 379, 245 P. 2d 239 (1952); Ceresia v. Mitchell, 242 S.W. $2 d 359$ (Ky. App., 1951); Burroughs Adding Machine Co. v. Chollar, 79 S.W. 2d 344 (Tex. Civ. App., 1935); Hill v. Central West Public Service Co., 37 F.2d 451 (C.A. 5th, 1930). Divisibility is also not required in most of the states where covenants restraining competition ancillary to the sale of businesses are expressly permitted by statute, note 26 infra.

24 The Torborg court thought that precedents for upholding restrictive covenants which grew out of the sale of a business were "not very helpful." Supra note 8 , at -, 588. And Lord MacNaghten once dištinguished the situations for the reason that "[a] man is bound an apprentice because he wishes to learn a trade and to practise it. A man may sell because he is getting too old for the strain and worry of business, or because he wishes for some other reason to retire from business altogether. Then there is obviously more freedom of contract between buyer and seller than between master and servant or between an employer and a person seeking employment." Nordenfelt v. Maxim Nordenfelt Guns and Ammunition Co., [1894] A.C. 535, 566. Most American courts bestow greater blessings upon restrictive covenants connected with business sales than with employment. Arthur Murray Dance Studios of Cleveland v. Witter, 105 N.E. 2d 685 (Ohio C.P., 1952); Betten Co. v. Brauman, 218 Wis. 203, 260 N.W. 456 (1935); Milwaukee Linen Supply Co. v. Ring, 210 Wis. 467, 246 N.W. 567 (1933). English courts.currently demonstrate the same tendency. Ronbar Enterprises, Ltd. v. Green, [1954] 1 Weekly L.R. 815 (C.A.). For the view that the considerations should be identical in the two areas, see Eureha I aundry Co. v. Long, 146 Wis. 205, 131 N.W. 412 (1911). (This view is no longer followed in Wisconsin.) Certainly in those states that prohibit covenants against competition by the employee, while permitting such covenants ancillary to the sale of a business, note 26 infra, a very basic difference is indicated. But while courts customarily give greater protection to an employee than to the seller of a business, it is uncertain whether the difference has resulted in a differing application of the doctrine of severability, i.e., whether there is greater hesitance to interpolate divisibility into an employee's covenant.

${ }^{25}$ No attempt has been here made to demonstrate the statistical extent of each view, particularly of the new "trend." Considerable commentary has dealt with the quantitative extent of the minority view, and most of the cases may be found in the authorities cited note 16 supra.

${ }^{26}$ Michigan (24 Mich. Stat. Ann. [Henderson, 1938] \$ 28.61) and Louisiana (16 La. Rev. Stat. Ann. [West, 1951] tit. 23, §921) prohibit expressly covenants restraining employees from competition. The Michigan statute makes an exception in permitting restrictive covenants in employment contracts which prohibit solicitation of employer's customers for a period of ninety days after termination of the employment contract. In Oklahoma "[e]very contract 
II

The basic conflict in this area is between the policy of upholding the right to exercise a lawful trade and the policy of effectuating freedom of contract by upholding the intention of the parties as far as possible. ${ }^{27}$ In determining whether a need for partial enforcement exists which may be consistent with the best interests of the public and the parties involved, ${ }^{29}$ it seems clear that any limitation on partial enforcement stemming from the doctrine of severability is irrelevant to the basic policy conflict; the question should be solely one of choosing the alternative between the view that covenants invalid when viewed as a whole may not be partially enforced, and the view that such covenants may be partially enforced to the extent they are valid. The irrelevance of severability

by which anyone is restrained from exercising a lawful profession, trade or business of any kind, otherwise than as provided by the next two sections, is to that extent void." Olila. Stat. (1951) tit. 15, $\$ 217$. The subsequent two sections permit one who sells the goodwill of a business, or the transferor of a partnership interest, to agree to refrain from carrying on a similar business within a specified county, city, or part thereof. The Alabama, California, and North Carolina statutes are similar to that of Oklahoma. Ala. Code $(19 \pm 0)$ tit. 9, $\S 22$; Calif. Bus. \&: Prof. Code (Deering, 1951) §§ 16600-16602; 1 N.D. Rev. Code (1943) § 9-0806.

South Dakota prohibits contracts in restraint of trade except in the case of sales of business and partnership interests. S.D. Code (1939) c. 10.06, \$10.0706. Also, "[a]n employee may" agree with an employer ... not to engage directly or indirectly in the same business or profession as that of his employer for any period not exceeding ten years from date of such agreement and within any specified territory not exceeding a radius of twenty-five miles from the principal place of business of the employer, as specified in such agreements, but such contracts between employee and employer shall apply only to those engaged in some profession, the practitioners of which must be duly licensed in the state of South Dakota." (Emphasis added.) Ibid., at c. 10.06, § 10.0706(3).

Though it has been argued that the above statutes which prohibit restraints of trade merely enact existing common law, it has usually been held in construing these statutes that all agreements by employees to refrain from competition are void. See E. S. Miller Laboratories, Inc. v. Grifin, 200 Okla. 398, 19ะ P. 2d 877 (19:8); Morris v. Harris, 127 Cal. App. 2d 476, 274 P. 2d 22 (1954); Wedin v. Atherholt, 298 Mich. 142, 29 S.W. 483 (1941).

In the above states where statutes permit restrictive covenants ancillary to the sale of a business, a covenant that is excessive when viewed as a whole will be partially enforced, notwithstanding the absence of divisibility, to the extent that they are valid. Waiver of divisibility requirements came about largely because the statutory terminology made restrictive covenants, other than those ancillary to the sale of a business, "void to that extent," viz., void to the extent that trade was unlawiully restrained. Thus a covenant by the seller of a business not to compete was void only to the extent it was unreasonably broad, and divisibility was not a prerequisite to partial enforcement. See IIahlstedt v. Fugit, $79 \mathrm{Cal}$. App. 2d 562, 180 P. 2d i77 (1947); Herrington v. Hackler, 181 Ok:la. 396, it P. 2d 388 (1937); General Paint Corp. v. Seymour, 124 Cal. App. 611, 12 P. 2d 990 (1932).

27 Commentary favoring each policy is abundant. Williston and Corbin favor the grantiag of partial enforcement irrespective of divisibility. Consult notes 28,35 infra. The Restatement apparently favors the rule of divisibility. Consult note 7 supra. Further, the Welcome Wagon view has been lauded, Duke B.J., op. cit. supra note 11.

${ }^{23}$ Corbin states that "[w]ith respect to partial illegality, the real issue is whether partial enforcement is possible without injury to the public and without injustice to the parties themselves. It is believed that such enforcement is quite possible in the great majority of cases." 6 Corbin, Contracts $\$ 1390$ (1951). 
can be seen most clearly by examining the arguments for and against partial enforcement. ${ }^{29}$

A common argument against the granting of partial enforcement under the Massachusetts and Torborg views is the familiar one against judicial interference by rewriting contracts. ${ }^{30}$ Analytically this is not an argument, but merely a restatement of the basic issue-whether it is desirable to grant partial enforcement. A more cogent argument against partial enforcement is that employers will be encouraged to draft unduly harsh restrictive covenants because they can be confident that no matter what the covenant provides they will receive the maximum protection of the law. ${ }^{31}$ Though this argument has been used against the doctrine of severability, in reality it militates against any type of partial enforcement and has no connection with severability. ${ }^{32}$

Proponents of partial enforcement argue that it is consonant with justice to promote freedom of contract by upholding the intent of the contracting parties to the maximum possible degree,$^{33}$ and since it is recognized that the employer's

29 "It renders no service to say that the answer [to whether partial enforcement may be granted].depends upon whether or not the contract is 'divisible.' 'Divisibility' is a term that has no general and invariable definition; instead the term varies so much with the subjectmatter involved and the purposes in view that its use either as an aid to decision or in the statement of results tends to befog the real issue." Corbin, ibid.

${ }^{30}$ See, e.g., Donahue v. Permacel Tape Corp., - Ind. -, 127 N.E. 2d 235 (1955). It may be observed that the policy of freedom of contract thus cuts both ways. That is, the policy may be said, on one hand, to require upholding the intention of the contracting parties to the maximum, or on the other hand, to require that courts permit parties to write their own contracts.

31 In Mason v. Provident Clothing and Supply Co., Ltd., [1913] A.C. 724, 745-46, Lord Moulton said that it would "be pessimi exempli if, when an employer had exacted a covenant deliberately framed in unreasonably wide terms, the Courts were to come to his assistance and, by applying their ingenuity and knowledge of the law, carve out of this void covenant the maximum of what he might validly have required. . . [ [T] he real sanction at the back of these covenants is the terror and expense of litigation, in which the servant is usually at a great disadvantage, in view of the longer purse of his master . . . the hardship imposed by the exaction of unreasonable covenants by employers would be greatly increased if they could continue the practice with the expectation that, having exposed the servant to the anxiety and expense of litigation, the Court would in the end enable them to obtain everything which they could have obtained by acting reasonably." Moulton wanted to sever covenants only where the excessive restraint was of trivial importance and not a part of the main substance of the clause. In dictum in Goldsoll v. Goldman, [1914] $2 \mathrm{Ch}$. 603, 613, Neville J. thought that if covenants went too far they should be void in toto. "To hold otherwise seems to me to expose the covenantor to the almost inevitable risk of litigation which in nine cases out of ten he is very ill able to afford, should he venture to act upon his own opinion as to how far the restraint upon him would be held by the Court to be reasonable, while it may give the covenantee the full benefit of unreasonable provisions if the covenantor is unable to face litigation."

32 The argument was originally directed to the traditional statement of the severability doctrine, ibid., but it has been more recently used to criticize the Massachusetts view of treating all covenants as divisible. Consult Application of the Rule of Severability to a Covenant in Restraint of Trade, $82 \mathrm{U}$. of Pa. L. Rev. 872 (1934). The fallacy of utilizing the argument against a liberalized construction of divisibility, but not to the "blue-pencil" test, was aptly shown in Employee's Agreement Not to Compete, 26 N.C.L. Rev. 402 (1948).

${ }^{33}$ In Foltz v. Struxness, $168 \mathrm{Kan} .714,215$ P. 2d 133 (1950), it was felt that equity should uphold contracts in harmony with justice and fairness and the expressed intention of the parties to protect an established business of the owner, and a restrictive covenant was en- 
interest deserves some protection, that protection which has been bargained for should be granted when there is no undue burden on the employee. ${ }^{34}$ It is claimed that this position will not encourage employers to oppress former employees by harsh restrictions since partial enforcement will not be granted if the restraints are deliberately unreasonable or oppressive. ${ }^{35}$ Granting the desirability of partial enforcement, the doctrine of severability can easily be criticized on the ground that legality of contracts should not depend solely upon mere matters of form ${ }^{36}$ This position seems impregnable since the only basis for the rule of severability is the desire to promulgate freedom of contract and that basis persists whether or not the particular language is literally divisible. ${ }^{37}$ Parties intending to impose certain restrictions should not be accorded different treatment because of the particular form of grammar used.

It is submitted that the question of severability is not relevant to a determination of when partial enforcement should be granted, and that where enforcement is made to depend upon judicial construction of severability or grammatical severance the basic issues are obscured or overlooked; if partial enforcement is desirable no cogent reasons exist for making its availability depend upon the grammatical structures of contracts. Accordingly the doctrine should be discarded as a means of determining whether partial enforcement will be granted. Further, in those jurisdictions that liberalize the doctrine to the point of treating all contracts as divisible it is recommended that the unequivocal rule of the Torborg case, which has the identical effect, be adopted. To say that all contracts are divisible is to say that divisibility is not required. Finally, it is obvious that severability is not relevant to the Welcome Wagon view, under which covenants are judged in their entirety.

forced to the extent necessary to carry out the protective intent of the parties, though the covenant was not divisible.

${ }^{34}$ Cf., Eldridge v. Johnston, 195 Ore. 379, 245 P. 2d 239 (1952); Hill v. Central West Public Service Co., 37 F. 2d 451 (C.A. 5th, 1930).

${ }^{35}$ Fullerton Lumber Co. v. Torborg, supra note 8 , at,- 592 . This is also Williston's view. 5 Williston, Contracts $\S 1660$ (rev. ed., 1937). This limitation on the power to grant partial enforcement would seem to require a determination of reasonableness upon two levels which might add a complicating factor. That is, in addition to an examination of whether the restriction is reasonable in reference to the employer's needs and the employee's rights, the court must, after a finding that the restriction was too broad, attempt to ascertain whether it was too unreasonable to countenance partial enforcement. Deliberate unreasonableness could only be shown by inference from an unconscionably oppressive restriction. Perhaps the limitation is but another way of saying that unconscionable contracts will be denied enforcement for want of equity.

${ }^{36}$ This is Williston's primary argument against the doctrine. 5 Williston, Contracts $\S 1660$ (rev. ed., 1937). The same argument was made in Partial Enforcement of Unreasonable Restraints, 22 Va. L. Rev. 94, 95 (1935) where it was said that "public policy does not demand that principle be sacrificed to technicalities of form."

${ }^{37}$ Martin, J., speaking for the court in the Torborg case, said, "[W]e do not see why the basic reason for such willingness to enforce a contract after removing terms which are literally divisible should not also exist in the case of indivisible promises where the evidence is ample to support a finding as to the extent the restriction would be necessary and valid." Supra note 8 , at,- 592. 